\title{
Tarihsel Perspektifle Geleceğe Projeksiyon: Dünya Devlerini Ortak Girişime İkna Etme
}

\author{
The Projection With Historical Perspective: Persuading Global Giants to Joint \\ Venture
}

Metehan Feridun SORKUN ${ }^{1}$, Meltem ONAY ${ }^{2}$

\begin{abstract}
ÖZET
Bu araştırma, bölgesel firmalarının küresel değer zincirine entegre olabilmelerinin doğrudan yollarından biri olan yabancı dev firmalar ile ortak girişimde bulunabilmenin öncül koşullarını ortaya çıkarmayı amaçlamaktadır. Küreselleşme ile hemen hemen her endüstride güç, belli firmaların elinde toplanmakta ve çok uluslu şirket halini alan bu dev firmalar gelişmekte olan ülke pazarlarını büyümek için hedef almaktadır. Bunun sonucunda ayakta kalmaları zorlaşan bölgesel firmaların ancak yetilerini ve organizasyon kültürlerini dev firmalarınkine tamamlayıcı olarak geliştirdikleri takdirde bu durumu lehlerine çevirmeleri mümkün gözükmektedir. Farklı zaman dilimlerinde bunu başarabilmiş iki Türk firmasına vaka analizi yapan bu araştırma, dev firmaları ortaklık teklif ettirecek noktaya getiren süreçlerin ortak noktalarını zamandan bağımsız olarak ortaya koymaktadır. Böylelikle bu araştırmanın sonuçları gelecekte Türk firmalarının dev firmalarla ortaklık yaparak küresel değer zincirine adapte olmak için hangi süreçleri izlemeleri gerektiğine dair bir projeksiyon tutacaktır. Bu araştırmanın sonuçları ayrıca sosyal sermaye ile uluslararası iş birliklerinin öncül dinamiklerini ilişkilendirerek önemli teorik katkılarda bulunmaktadır.
\end{abstract}

Anahtar Kelimeler: sosyal sermaye, asimetrik ilişki, stratejik ortaklık, ortak girişim, partner seçme kriterleri, sosyal yerleşiklik, öğrenen organizasyon, sosyal network.

\section{GiRiş}

Küreselleşmenin etkisi ile çok uluslu dev şirketlerin gelişmekte olan ülke pazarlarındaki payı gün geçtikçe artmaktadır. Ortaya çıkan bu trend, rekabetçiliğin korunması adına bölgesel firmaları yeni stratejik kararlar almaya zorlamaktadır. İzlenecek stratejilerden birisi, yabancı güçlü firmaların tamamlayıcı yeti ve kaynaklarından yaralanarak küresel değer zincirine entegre olmak olarak gözükmektedir (Giuliani vd.,

\begin{abstract}
This research aims to reveal the pre-conditions for local firms to form a joint venture with global giant firms, which is one of the most direct ways to integrate into global value chain. With globalization, the power concentrates into the hands of few firms in almost all industries. These firms, which have become multi-national enterprises, target the markets of developing countries for further growth. Thus, local firms under pressure may convert this difficulty to their favour only if they can develop capabilities and create a congruent organizational culture to the those of giant firms. This research makes a case study on two Turkish firms that drew the attention of giant firms leading to the joint ventures formed in different time periods. By examining the activities of two case firms before their forming joint venture, this research finds the commonalities across two cases regardless time. Therefore, the results of this research provide a guidance to Turkish firms on what they need to do in future for drawing the attention of giant firms. the results indicate an important theoretical contribution by linking the social capital theory to the pre-conditions of international strategic alliances.
\end{abstract}

Keywords: social capital, assymmetric relationship, strategic alliance, joint venture, partner selection criteria, social embeddedness, organizational learning, social network

2005). Ancak, dünyada sektörünün lideri olan çok uluslu şirketlerin ortaklık için aradığı kriterlerin bir hayli talepkâr olduğu bilinmektedir (Hitt vd., 2000; Prashantham ve Birkinshaw, 2008). Bunun yanı sıra, birçok bölgesel firmanın da böyle bir ortaklığa istekli olması evlilik için rekabeti bir hayli arttırmaktadır. Sonuç olarak yabancı güçlü firmalar ile ortaklık kurabilmek için bölgesel firmaların çok üst seviyede özelliklere sahip olması gerekmektedir. 
Farklı tarihsel dönemlerde Türk firmalarının dünya devleri ile yaptığı başarılı ortaklıkları dikkate alan bu araştırma, gelecekte Türk firmalarının bu tür ortaklıklar için ne yapmaları gerektiğine ışık tutmayı amaçlamaktadır. Bir diğer ifadeyle bu araştırma, Türk firmaları yıllar içerisinde hangi faaliyetlerde bulunurlarsa, sektöründe dünya devi olan firmalara ortaklık için çekici hale gelebilirler sorusuna yanıt aramaktadır. Bu şekilde öğrenilecek bilginin, gelecekte başarılı olmak isteyen diğer Türk işletmelerine de bir model, bir argüman, bir derleme ya da vizyon sunması amaçlanmaktadır.

Araştırmanın amacını gerçekleştirmek için Türkiye'de yabancı ortaklığı bulunan iki firmanın ortaklık öncesi durumlarının üzerine analiz yapılmıştır. İncelenen bu Türk firmaları, sektörlerinin liderlerinden olan yabancı dev firmalar ile farklı zaman dilimlerinde ortak girişimde bulunmuşlardır. Dolayısıyla incelenen bu iki Türk firması da yabancı dev firmaların kriterlerini ortaklık kurulduğu zamanın özgün piyasa koşullarında karşılamayı başarabilmişlerdir. Bu iki vaka karşılaştırılarak, isimleri zamanla değişse de karşılanması gereken kriterlerin temelde aynı olduğu ortaya konmuştur. Böylece bu araştırmanın yaptığı projeksiyon, Türk firmalarının gelecekte hangi yollarla dev firmalar tarafından aranan kriterleri karşılayabileceğine ışık tutmuştur.

Araştırmanın sonuçları hem teorik hem de yönetimsel olarak önemli çıkarımlar yapmaya imkân vermektedir. Öncelikle sosyal sermaye teorisi çerçevesinde Bourdieu (1980); ilişki kalitesi, organizasyon kültürü ve müşteri portföyü gibi firmaların maddi olmayan birikimlerinin ileride ekonomik değere de dönebileceği ortaya konduğu gibi bu birikimlerin oluşmasını sağlayacak aktiviteler de uluslararası iş birliği anlaşmaları çerçevesinde gösterilmiştir. Ek olarak bu araştırmada farklı zamanlarda yaşanmış iki başarılı örneğin ortak noktalarının gösterilmesi zamanın değişen şartlarına adapte olabilecek bir model ortaya çıkarmaktadır. Böylelikle bu araştırma, gelecekte benzer şekilde dev firmalar ile ortaklık yapmak isteyen Türk firmalarına projeksiyon tutacaktır.

\section{LITERATÜR ÖZETI}

\subsection{Stratejik Ortaklıklar ve Türleri}

Stratejik ortaklıklar, belirlenmiş bir hedefi gerçekleştirmek üzere birden fazla firmanın kaynaklarının (fiziksel, insani) ve fikri mülkiyet haklarının bir kısmını veya tamamını bir araya getirmesiyle yaptıkları iş birlikleridir (Gulati, 1998). Her stratejik ortaklığın yürütülmesi sırasında ortakların birbirine karşı taşıdığı sorumluluklar ve entegrasyon seviyeleri farklılık gösterir. Bazı stratejik ortaklıklar sadece bir işletme fonksiyonunu (pazarlama, araştırma vb.) güçlendirmek için hükümleri bağlayıcı olmayan bir iyi niyet anlaşması üzerinde kalabilirken, firmalar arasındaki iş birliği tüzel kişiliği farklı ortak bir şirket kurulmasına kadar gidebilir (Dacin vd., 1997). Todeva ve Knoke (2005) stratejik ortaklıkların yürütülmesi sırasında firmaların entegrasyon seviyelerini dikkate alarak Tablo 1'de gösterildiği üzere stratejik ortaklıkları kategorize etmiştir. 
Tablo 1: Stratejik Ortaklık Türleri (Kaynak: Todeva ve Knoke, 2005)

\begin{tabular}{|c|c|}
\hline Ortak Girişim & $\begin{array}{l}\text { İki veya daha çok firmanın kendi menfaatlerine hizmet eden ve tüzel kişiliği ayrı olan } \\
\text { bir şirket kurdukları stratejik ortaklık türüdür. }\end{array}$ \\
\hline Sermaye Yatırımı & $\begin{array}{l}\text { Bir firmanın diğer bir firmanın sermayesinin az veya çok kısmını direk satın alma } \\
\text { yoluyla elinde bulundurduğu bir stratejik ortaklık türüdür. }\end{array}$ \\
\hline Kooperatif & $\begin{array}{l}\text { Küçük işletmelerin bir araya gelerek kaynaklarını kolektif bir şekilde yönettikleri ve } \\
\text { koordine ettikleri bir stratejik ortaklık türüdür. }\end{array}$ \\
\hline $\begin{array}{l}\text { Ar-Ge } \\
\text { Konsorsiyumu }\end{array}$ & $\begin{array}{l}\text { Genellikle hızlı teknolojik değişimin yaşandığı sektörlerde firmaların araştırma ve } \\
\text { geliştirme yapmak için iş birliği yapmasıdır. }\end{array}$ \\
\hline $\begin{array}{l}\text { Stratejik İş Birliği } \\
\text { Anlaşması }\end{array}$ & $\begin{array}{l}\text { Bir kontrat çerçevesinde birçok firmanın iş birliği yaparak stratejik kararlar vermesi ve } \\
\text { ortaya çıkan sonuçların paylaşıldığı bit stratejik ortaklık türüdür. }\end{array}$ \\
\hline Kartel & $\begin{array}{l}\text { Büyük firmaların kendi aralarında anlaşarak piyasadaki üretim miktarını ve fiyatı } \\
\text { manipüle etme yoluyla piyasadaki rekabeti kendi lehlerine çevirmeyi amaçlar. }\end{array}$ \\
\hline İmtiyaz Anlaşması & $\begin{array}{l}\text { Bir firma, diğer bir firmaya belli bir coğrafi alanda marka ismini kullanma hakkını verir; } \\
\text { fakat ücret, pazarlama ve servis süreçlerindeki kontrolünü sürdürür. }\end{array}$ \\
\hline Lisans Anlaşması & $\begin{array}{l}\text { Bir firma diğer bir firmaya belli bir bedel karşılığı patentli teknolojisini veya üretim } \\
\text { süreçlerini kullanma hakkını verir. }\end{array}$ \\
\hline Taşeron Ağı & $\begin{array}{l}\text { Taşeron firma, tedarikçilerinin uzun dönemli fiyat, üretim planları ve teslim çizelgeleri } \\
\text { üzerinde müzakere ederek bu ağda bulunan firmalara avantajlı bir iş ortamı } \\
\text { sağlamayı amaçlar. }\end{array}$ \\
\hline $\begin{array}{l}\text { Endüstri Standart } \\
\text { Grupları }\end{array}$ & $\begin{array}{l}\text { Kurulan komiteler yoluyla ticaret ve üretim faaliyetlerinde teknik standartları } \\
\text { oluşturmak için üyelerinin anlaşmasını sağlamayı amaçlar. }\end{array}$ \\
\hline Aksiyon Grupları & $\begin{array}{l}\text { Kısa süreli kurulmuş koalisyonlar olup lobi yaparak politika belirleyicilerinin kararlarını } \\
\text { etkilemeyi amaçlarlar. }\end{array}$ \\
\hline
\end{tabular}

\subsection{Ortak Girişimler}

Stratejik ortaklık türleri (Tablo 1) incelendiğinde, ortak girişimlerin yapısı itibariyle bu araştırmanın amacına daha iyi hizmet ettiği gözükmektedir; çünkü ortak girişimlerde firmalar arasındaki bağımlılık seviyesi diğer stratejik ortaklık türlerine göre daha yüksek seviyededir (Borys ve Jemison, 1989). Ortak girişimde (joint venture), iki veya daha çok firma ortak amaçlarına hizmet eden, fakat tüzel kişiliği ayrı olan bir şirket kurarlar (Kogut, 1988). Örneğin diğer bir stratejik ortaklık türü olan "imtiyaz anlaşmalarında (franchising)" ise imtiyazı alan firmaya sadece belli bir coğrafi bölgede marka kullanım hakkı verilir (Nijmeijer vd., 2014). Dolayısıyla ortak girişim kurma kararı diğer stratejik ortaklık türlerine nazaran daha riskli ve geri dönülmesi daha maliyetlidir. Ortak girişimlerin bu yapısı, ortaklık öncesi aranan kriterleri daha yükseltmekte ve bu kriterlerin nasıl karşılanabileceği sorusunun cevabını da daha değerli hale getirmektedir.
Taşıdıkları nispeten daha fazla riske karşın ortak girişimlerin getirdiği önemli avantajlar da bulunmaktadır. Kogut (1988) bu unsurları üç başlık altında toplamıştır. Illk olarak firmalar kurdukları ortaklıklar sayesinde işlem maliyetlerini azaltabilmektedirler. Ortaklar arasındaki güven; işlemlerin tanınması, ölçülmesi ve kontrol edilmesi süreçlerindeki harcanması gereken çabayı azaltmaktadır. Ortakgirişimleri teşvikeden ikinci unsur ise firmaların pazardaki güçlerini ve rekabetçiliklerini arttırma arzularıdır. Yapılan ortak girişim çerçevesinde bir araya getirilen kaynakların birbirini tamamlayıcı olması durumunda hedef pazarlarda önemli rekabetçi avantajlar elde edilebilecektir. Üçüncü ve son olarak, ortak girişimler, firmaların öğrenme süreçlerine ciddi biçimde katkıda bulunmaktadırlar. Ortakların birbiriyle olan yakın etkileşimi, her bir ortağın güçlü yanlarının diğeri tarafından gözlemlenerek transfer edilmesini kolaylaştırmaktadır. Bu durum ikinci unsura tekrar destek olarak, ortaklık kuran firmaları pazarda daha rekabetçi hale getirmektedir. 


\subsection{Asimetrik iliş̧ki Perspektifinden Ortak Girişimleri Cazip Kılan Faktörler}

Ortak girişimleri oluşturan firmalar benzer büyüklükte olacakları gibi özellikle küreselleşmenin etkisiyle ortaklar arasında güç dengesinin farklı olduğu ortak girişimlerin de varlığı göze çarpmaktadır (Prashantham ve Birkinshaw, 2008; Barabel vd., 2015). Genellikle çok uluslu firmalar ile bölgesel firmaların kurduğu bu tür stratejik ortaklıklar "asimetrik stratejik ortaklık" olarak tanımlanmaktadır (Chen ve Chen, 2002). Asimetrik ortak girişimler kurulurken, çok uluslu dev firmaların ve bölgesel firmaların ayrı motivasyonlarının olduğu göze çarpmaktadır (Dacin vd., 1997).

Çok uluslu dev firmaların büyüme stratejilerinde yeni pazarlara açılmak kritik bir öneme sahiptir. Bu kapsamda girilecek pazarı iyi tanıyan bölgesel bir firma ile ortaklık başarılı bir pazara giriş sürecini beraberinde getirecektir (Geringer, 1991). Başarı oranının arttırılması dışında pazara özel politik, bürokratik ve çevresel riskler de pazarı iyi bilen bölgesel firma sayesinde bir hayli azalacaktır (Delios ve Henisz, 2000). Dev firmaların belli bir ülkedeki firma ile ortak girişimde bulunması sadece o ülke pazarını hedef aldığını göstermeyebilir. Örneğin ortaklık kurulan bölgesel firmanın üretim tesisleri coğrafi olarak önemli bir konumda ise veya hali hazırda bulunan ihracat portföyü geniş bir coğrafyaya yayılmışsa, dev firmalar yapılacak ortaklık sayesinde birçok pazara hızlı bir giriş yapabileceklerdir (Carnovale ve Yeniyurt, 2014).

Bölgesel firmaların dev firmalarla ortak girişimlerde bulunma isteklerinin ise daha farklı nedenlere dayandığı göze çarpmaktadır. Öncelikle bölgesel firmalar bu tür ortaklıklarla küresel değer zincirine entegre olmayı başarabilmektedirler. $\mathrm{Bu}$ durum kendilerine bir bilinirlik ve güven duyulmasını sağlayacak; böylece markalaşmalarını kolaylaştıracaktır. Ayrıca asimetrik olarak tanımlanan ortak girişimlerde, bölgesel firmaların dev ortaklarından hem kurumsallaşma hem de üretim süreçleri gibi teknik konularda çok şey öğrenme fırsatları olacaktır (Hamel, 1991). Bunlara ek olarak, dev firmaların ortaklarına sağlayacağı finansal olanaklar, bölgesel firmaların projelerini daha hızlı şekilde hayata geçirmesini temin edecektir (Geringer, 1991; Prashantham ve Birkinshaw, 2008). Unutulmaması gereken bir diğer kritik nokta ise, eğer dev firmalar bir pazara girmeye niyetlenirse, bir şekilde bunu gerçekleştirecektir. Bu durum dikkate alındığında, pazara giriş yapan dev firmaların rakibi olmak yerine onlarla ortaklık kurarak kaynaklarından istifade etmek daha mantıklı bir strateji olarak gözükmektedir (Glaister ve Buckley, 1996).

Yukarıdaki faktörler düşünüldüğünde dev firmalar ile yapılan ortak girişimler (şartları çok zorlu olmadığı sürece) bölgesel firmalar için oldukça karlı görünmektedir. Bu yüzden, dev bir firmanın herhangi bir pazara yatırım yapacağı dedikodusu çıkar çıkmaz, bölgesel firmaların olası bir ortak girişim için nabız yoklayacaklarını varsaymak yanlış olmaz. Bu konjonktürde, çok uluslu dev firmalarının ortaklık için bir hayli fazla alternatifi bulunmaktadır. Dolayısıyla pazarlık gücünü elinde bulunduran dev firmaların ortaklık için aradığı kriterler de bir hayli zorlu olmaktadır (Inkpen ve Beamish, 1997). Özellikle dev firmalar, hali hazırda büyük bir finansal güce sahip olduğu için, fiziksel sermayesinden daha çok ortaklık yapacağı firmada güven, deneyim, kültür ve bilgi gibi sosyal sermayeyi oluşturan unsurları dikkate alabilmektedir (Tatoglu, 2000).

\section{TEORIK ALT YAPI}

Sosyal sermaye, son zamanlarda firmaların rekabetçiliğini açıklamak için üzerinde sıkça durulan kavramlardan birisi olmaktadır. Bourdieu (1980) sosyal sermayeyi, firmaların var olan ve potansiyel olarak kullanılabilecek kaynaklarının toplamı olarak tarif etmektedir. Adler ve Kwon (2002) bu çerçevede sosyal sermayeyi sadece fiziksel sermaye ile sınırlamayıp değer yaratmayı kolaylaştıran her türlü firmalar ve bireyler arasındaki ilişkiler olarak tanımlamaktadır. Bu tanıma göre, firmaların ekosistemlerinde bulunan aktörlerle olan ilişkilerinin şekli, organizasyon kültürleri ve deneyimleri gibi etkenler firmaların sosyal sermayesini oluşturmakta ve onlara ekonomik değer oluşturmaktadır (Biggart and Castanias, 2001).

Nahapiet ve Ghoshal, (1998) sosyal sermayenin boyutlarını i) yapısal, ii) iliş̧kisel ve iii) bilişsel olarak belirtmektedir. Bu boyutların ilki olan yapısal boyut dikkate alındığında, firmanın küresel network ağı içerisindeki stratejik pozisyonda olması sosyal sermayesini güçlendirecektir. İkinci bileşen olan ilişkisel boyut ise belli bir network ağında bulunan firmaların arasındaki ilişkinin şekline vurgu yapmaktadır. Dolayısıyla geçmişte bir firmanın yaşamış olduğu pozitif deneyimler, ileride kuracağı ilişkilerin kalitesinin de yüksek olacağına işaret etmektedir. Son ve üçüncü bileşen olan bilişsel boyut ise organizasyonların kültürel 
öğelerini öne çıkarmaktadır. Firmaların bu zamana kadar edinmiş olduğu değerler ve yapmış olduğu gelişim ekosistemlerine pozitif bir algı yaratarak sosyal sermaye güçlerini arttıracaktır (Kangal,
2013). Şekil 1'de, her bir düz ok sosyal sermayenin boyutlarını ${ }^{1}$ simgeler iken çizgili oklar her bir boyut ile ilişkilendirilen teorileri göstermektedir.

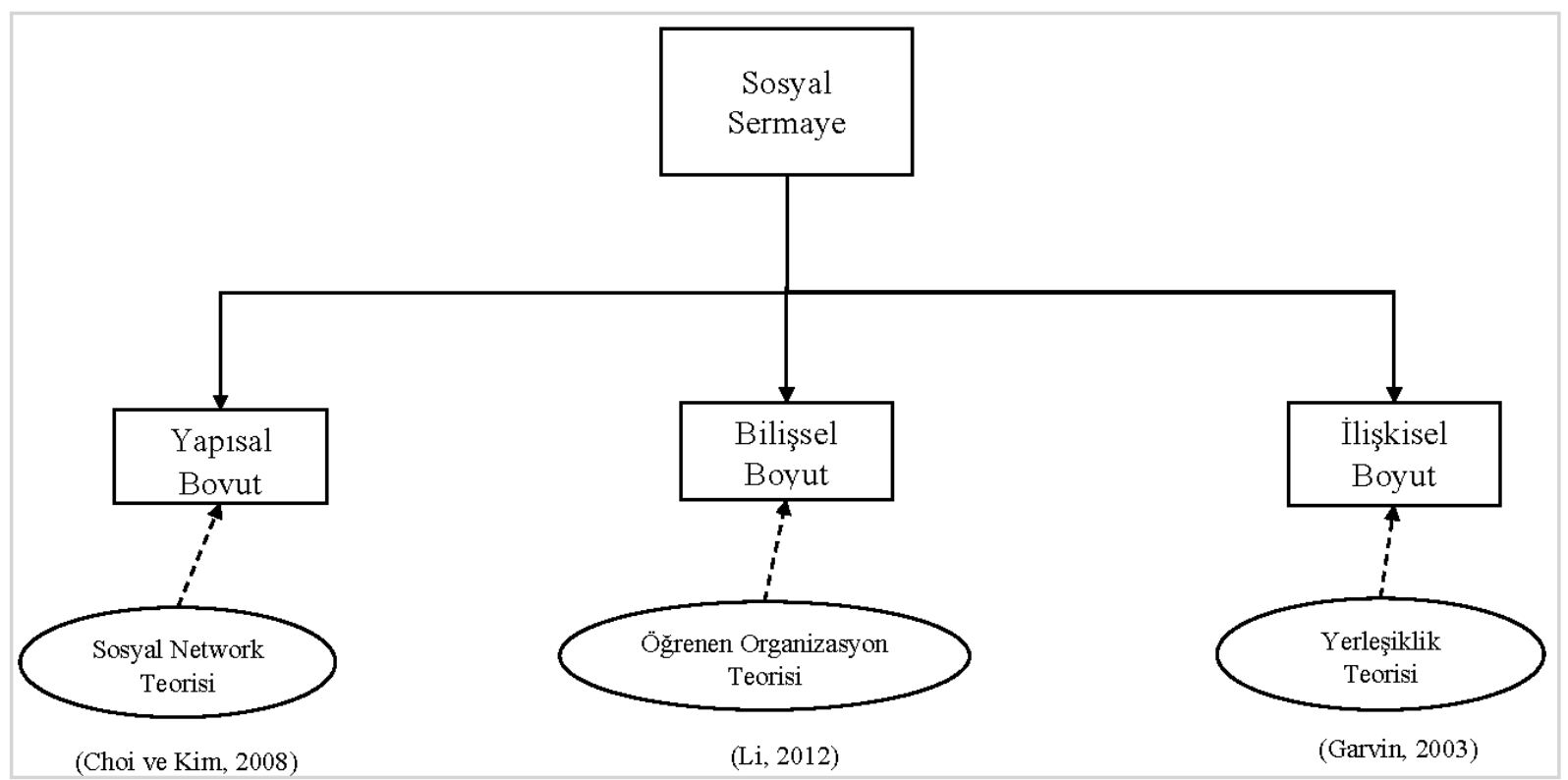

Şekil 1: Sosyal Sermayenin Boyutları

Sosyal network teorisi, belli bir grup içerisindeki aktörlerin etkileşimini inceler (Choi ve Kim, 2008). Firmaların ve paydaşlarının aktör olduğu bir network ağının analizi, incelenen ilgili firmanın sosyal sermayesinin seviyesi hakkında ipuçları verecektir. Örneğin ilgili firmanın network ağının büyük olması, pozisyonunun network içerisinde merkezi olması (diğer network aktörleriyle çok sayıda ilişkisi olması), köprü vazifesi görmesi (farklı grup aktörleri birbirine bağlaması) veya ilişkisi olduğu aktörlerin o network içinde nüfuz sahibi olması gibi tüm faktörler firmanın ekosistemindeki intiyaç duyduğu kaynaklara daha kolay ulaşmasını sağlayacaktır (Otte ve Rousseau, 2002). Bugüne kadar yapılan çalışmaların sonuçları da bu teoriyi desteklemektedir. Örneğin uluslararası pazarlara girebilen Tayvan firmalarını inceleyen Chen ve Chen (2002), bu firmaların network ağında nüfuz sahibi olan yabancı dev firmalar ile ortaklık kurarak bunu başarabildiklerini göstermektedir. Aynı şekilde, Carnovale ve Yeniyurt'un (2014) otomotiv endüstrisi üzerine yaptığı çalışma da network ağı daha büyük olan ve network ağında köprü vazifesi gören firmaların daha rahat ortak girişim kurduklarını göstermektedir.
Sosyal yerleşiklik, bir network ağı içerisindeki aktörlerin bulunma sürekliliğini, yeni ilişkiler kurabilme ve var olan ilişkilerini geliştirebilme düzeylerinin sonuçları ile ilgilenmektedir (Li, 2012). Dolayısıyla "yerleşiklik", konsept olarak ekonomik network ağları için de kullanılabilecek olup, firmaları geçmiş ilişkileriyle ve diğer firmalarla bugüne kadar yapmış olduğu etkileşimlerle resmetmektedir. Bu bakış açısıyla, bulunduğu network ağı içerisinde geçmiş ilişkilerinde başarılı olarak gözüken firmalar sosyal sermayesinin ilişkisel boyutuna pozitif katkıda bulunmaktadırlar. Örneğin Inkpen ve Currall'ın (1998) ortak girişimlerde güvenin öncül koşullarından birinin firmaların daha önce yaptıkları başarılı iş birlikleri olduğunu belirtmektedir. Bu yazarların düşüncelerine göre geçmişinde başarılı iş birliklerinde bulunan firmalar, ileride de uzun ve başarılı iş birlikleri kurabileceklerdir; çünkü ortaklığın ilk periyodunda oluşabilecek kırılganlıkları firmaların ortaklık deneyimleri sayesinde gidermek daha kolay olacaktır. Daha önemlisi, ortalık tecrübesi olan firmalar, birlikte çalışabilme kültürüne sahip olduğundan ilgili süreçleri daha efektif ve sorunsuz yürütecektir. Tüm bunlar başarılı bir ortaklık kurmak isteyen firmaların 
ortak seçerken geçmiş ilişkileri değerlendirmesinin gerekliliğini ortaya koymaktadır (Park vd., 2015).

Bugün artık değişimin gerekliliği değil, organizasyonların bu değişimlere nasıl uyum sağladıkları konuşulmaktadır. Öğrenen örgüt; bilgiyi yaratma, edinme ve aktarma, yeni bilgi ve kavrayışları yansıtmak için davranışı değiştirme becerilerine sahip olan örgüt demektir (Garvin, 2003). Bu becerilere sahip olmanın en önemli koşullarından biri ise örgüt içerisinde çalışan kişiler tarafından paylaşılan vizyondur (Marquardt, 1996). Öğrenen organizasyon olmayı başarabilmiş firmalar, genel anlamıyla iki nedenden dolayı diğer firmalar tarafından ortaklık için cazip olacaktır. İlk olarak, öğrenen organizasyonlar çevre şartlarına kolayca adapte olabildiğinden kurulan ortaklığın başarı şansını yükselteceklerdir. İkinci olarak ise daha büyük hedeflere ulaşmak için elde edilen rantın paylaşılması gerektiğinin farkında olduklarından ortakları ile güvene dayalı ilişkiler kurabileceklerdir.

\section{ARAŞTIRMANIN YÖNTEMI}

$\mathrm{Bu}$ araştırma Türk firmalarının sektöründe lider olan firmalar ile gelecekte ortaklık kurma noktasına gelebilmeleri için nasıl bir süreçten geçmeleri gerektiğini açıklamayı hedeflemiştir. Fakat hiç olmadığı kadar hızlı değişen piyasa koşullarının dünün tasarlanmış modellerini gelecekte geçersiz kılabileceği göz önünde bulundurularak farklı zaman dönemlerinde yapılmış başarılı ortaklıklar ele alınmıştır. Böylece dev firmaları ortaklık teklif ettirecek noktaya getiren süreçlerin ortak noktalarının zamandan bağımsız olarak ortaya konması hedeflenmiştir. Bu şekilde öğrenilecek bilginin, gelecekte benzer şekilde başarılı ortaklık kurmak isteyen diğer Türk işletmelerine de bir model, bir argüman, bir derleme ya da vizyon sunması amaçlanmıştır.

Yöneltilen "neden" ve "nasıl" sorularının cevabını bulmak için toplanan verilerin nitel olmasının bu araştırmanın amacına daha iyi hizmet edebileceği düşünülmüştür (Eisenhardt, 1989; Yin, 2013). Ayrıca elde edilen verilerin farklı kaynaklardan alınmış olmasının araştırma sorularına yönelik elde edilen bulguların doğruluğuna olan güveni arttıran bir faktör olduğu göz önünde bulundurulmuştur. Tüm bunlar dikkate alınarak, derinlemesine yüz yüze yapılan görüşmeler ile verilerin toplandığı çoklu vaka analizi araştırma yöntemi olarak seçilmiştir.

\subsection{Vaka Analizi için Örneklemin Belirlenmesi}

Vaka analizi için örneklemenin teorik bir yöntem ile yapılması araştırmanın kalitesine işaret eden önemli bir göstergedir (Eisenhardt, 1989). Bu doğrultuda örneklem dikkate alınırken analiz biriminin doğru seçilmesi, araştırma sınırlarının iyi belirlenmesi ve seçilmiş olan örneklemlerin yapılan araştırmayla ilişkili olması gerekmektedir (Zirpoli ve Becker, 2011).

Araştırmada analiz birimi, Türk firmalarının dünyada sektöründe lider olan firmalar ile yaptığı ortak girişimler olarak belirlenmiştir. Bu araştırmada örneklenen ortak girişimlerden biri "Istaş ile Petrofer" arasında; diğeri ise "Inci Akü ile GS Yuasa" arasında yapılan olmuştur. Petrofer'in dünyada petrokimya sektörününliderfirmalarından biriolması, GSYuasa'nın ise akü sektörünün dünyada öncü firmalarından bir tanesi olması sebebiyle yapılan araştırmaya uygun seçimler oldukları düşünülmüştür. Örneklem seçiminde ikinci dikkat edilen husus ise örneklenen ortak girişimlerin farklı zaman periyodlarında fakat aynı coğrafi bölgede (İzmir) seçilmeleri olmuştur. Böylece çevresel diğer koşullar sabit tutularak, farklı zaman periyodlarında Türk firmalarının yabancı dev firmalarla ortak girişim yapabilmesini sağlayan ortak noktaların ortaya çıkarılması hedeflenmiştir. Bu kapsamda, Petrofer ve Istaş'ın 1995 yılında yaptığı ortak girişim ile Inci Akü ve GS Yuasa'nın 2015 yılında yaptığı ortak girişim araştırmaya uygun bir örneklem olmuştur. Son olarak, ortak girişimde yabancı firmaların ortaklık yüzdelerinin Türk firmalarınınki kadar olmasına dikkat edilmiştir. Böylece, yabancı firmaların bu ortaklıklarda önemli bir sermayesi bulunması sebebiyle ortak seçiminde ince eleyip sık dokuyacakları varsayımı yapılarak Türk firmalarının gerçekleştirdiği bu ortaklıkların bir başarı hikayesi olarak adlandırılabilmesi sağlanmıştır. Petrofer ve GS Yuasa'nın paylarının örneklediğimiz ortak girişimlerde yüzde elli olması, bu noktada da seçtiğimiz örneklemin araştırmanın amacına hizmet ettiğini göstermektedir.

\subsection{Verilerin Toplanması}

Araştırma için farklı kaynaklardan faydalanılarak verilerin elde edilmesine özen gösterilmiştir. Böylece toplanan verilerin doğruluğu teyit edilebilmiştir. İlk etapta şirketlerin internet sayfaları ve basında yer alan haberleri incelenmiştir. Bu yapılan ön araştırma sayesinde firmaların profilleri ve tarihçeleri hakkında geniş bilgiye ulaşılmıştır. Elde edilen bu bilgiler, yüz yüze yapılacak olan görüşmelerde sorulacak 
soruların araştırmanın amacına doğrudan hizmet edecek şekilde hazırlanmasını sağlamıştır. Yapılan görüşmelerin gidişatını bu hazırlanan sorular belirlemiş ve her bir mülakat 1-2 saat civarında bir süre tutmuştur. Yarı yapılandırılmış mülakat şeklinde yürütülen görüşmelere araştırmanın iki yazarı birden katılmıştır. Bir yazar hazırlanan soruları ilgili muhataplarına iletirken diğer yazar ise konunun dağıldığı noktalarda müdahale edip planlanan akışa dönülmesine yardımcı olmuştur. Mülakatlar sırasında elde edilen cevaplar kayıt altına alınmış ve görüşme sonrası görüşülen kişilere gönderilerek doğrulukları için teyit alınmıştır. Ayrıca görüşülen kişilerden araştırmada isimlerinin kullanılması için gerekli izinler alınmıştır.

İnci Akü - GS Yuasa ortak girişimini incelemek için ilk görüşme ortaklık görüşmelerinde aktif olarak bulunan Maxion Jantaş CEO'su velnci Holding yönetim kurulu üyesi Mustafa Zaim ile yapılmıştır. Daha sonra GS Yuasa'nın Japon yöneticisi şimdi ise ortaklıkta Genel Müdür Yardımcısı olan Yuji Hashimoto ile görüşülerek ortak seçerken GS Yuasa'nın kriterlerinin ne olduğu ve niçin İnci Akü'de karar kıldıkları sorulmuştur. Elde edilen bilgiler doğrultusunda İnci Akü'nün Genel Müdürü Cihan Elbirlik ile görüşülmüş ve İnci Akü'nün GS Yuasa ile hangi özellikleri sayesinde ortaklık kurabildiğini düşündükleri sorulmuştur. Daha önemli olan nokta ise bu özellikleri hangi süreçlerle elde ettikleri derinlemesine irdelenmiştir.

Araştırmanın diğer incelediği ortak girişim olan "Istaş ve Petrofer" için Petrofer Türkiye'nin Yönetim Kurulu Başkanı Tamer Taşkın ile temasa geçilmiştir. Inci GS Yuasa örnekleminde izlenen yöntem, aynı şekilde Petrofer Türkiye için de uygulanmıştır. Ilk olarak Petrofer'in ortak seçerken dikkate aldığı kriterlerin neler olduğu sorulmuştur. İnci GS Yuasa örnekleminde olduğu gibi yabancı ortak yöneticisi ile yüz yüze görüşülemese de Petrofer Yönetim Kurulu Başkanı Bay Fischer ile e-mail kanalıyla temasa geçilmiştir. Kendisine Petrofer'in ortaklık kurmadan önce hangi kriterleri dikkate aldığı sorulmuştur. İkinci aşamada ise Istaş firmasının nasıl bir yol izleyip de sektörünün dev firmalarından olan Petrofer'in kriterlerini karşılayıp ortak girişim için tercih edilebildiği Tamer Taşkın ile yüz yüze görüşülerek tespit edilmiştir.

\subsection{Verilerin Analizi}

Mülakatlar sırasında araştırmanın yazarları tarafından tutulan notlar yazarların birbirleri arasında paylaşılmıştır. Önce, her bir yazar bu tutulan notlar üzerinde bireysel olarak çalışmış ve bu notları araştırma sorusuna ışık tutacak şekilde kodlamıştır (Yin, 2013). Daha sonra her bir yazar kodladığı notlarının içerisinden araştırma sorusuna en ilişkin olanları belirlemiştir. Bireysel inceleme süreci tamamlandıktan sonra, yazarlar bir araya gelerek bireysel mülakat özetlerini birbirleriyle münazara ettiği toplantılar yapmışlardır. Toplantılar sırasında, mülakatlarda alınan cevapların araştırma sorularına ilişkilendirilmesi aşamasında fikir ayrılığına düşünülen noktalarda tekrar bireysel çalışmaya dönülmüştür. Bu süreç tüm konularda fikir birliğine varılana dek sürdürülmüştür.

\section{5. ÖRNEKLENEN FIRMALAR HAKKINDA GENEL BILGi}

\subsection{Istaş}

Tamer Taşkın 1979'da Istaş Işıl İ̧̧lem Sanayileri A.Ş'nin temellerini atmıştır. Istaş, ilk etapta Almanya'daki endüstriyel yağ üretimi yapan Petrofer'in ithalatçısı olmuştur. Daha sonra Petrofer'in o zaman temsilciliğini yaptığı Türk firmasından 10 kat fazla satış yapacağının teminatını vermiş ve bunu başararak Petrofer'in Türkiye'deki yeni temsilcisi olmuştur. Yıllar boyunca Petrofer ile süren ilişkisinin ardından Petrofer'i 1995 yılında İzmir'de fabrika kurdurmaya ikna etmiş ve böylece Istaş ve Petrofer'in oluşturduğu ortak girişim "Petrofer Türkiye" ismini almıştır. Şu anda "Petrofer Türkiye"; Afrika, Ortadoğu, Türki Cumhuriyetleri olmak üzere toplam 47 ülkeye ihracat yapan başarılı bir işletmedir.

\subsection{Petrofer}

1948 yılında Bruno Eberenz tarafında kurulan Alman firması petrokimya endüstrisinde sürekli gelişmiş ve 2016 yılı itibariyle de çeşitli yatırım ve ortaklıklarla 42 farklı ülkede faaliyet göstermekte olan bir firma olmuştur. Avrupa'nın ileri gelen araştırma kurumları ve sanayi uzmanları ile yakın işbirliği sonucunda geliştirilen Petrofer ürünlerinin çevreyle uyum özelliği, dünya pazarında firmayı lider konumuna getirmiştir. Petrofer'in ticari faaliyetleri; petrol ürünlerinin ticareti, çelik ürünlerinin ticareti ve kimyasal ürünlerin ticareti olmak üzere üç ana kola ayrılmaktadır. Endüstriyel sıvı yağlayıcıları ve süreç teknolojileri gibi ürünlerde dünya lideri olan şirket, 600 'den fazla çeşit endüstriyel yağ ve kimyasal ürünü müşterilerinin hizmetine sunmaktadır. 


\section{3. İnci Akü}

İnci Akü, 1984 yılında Cevdet İnci tarafından kurulmuş olan bir Türk firmasıdır. 1985 yılında Manisa'da ilk üretim merkezini açan İnci Akü, kuruluşundan itibaren yabancı firmalar ile yaptığı iş birlikleriyle dikkat çekmektedir. 1985 yılında Baren firması ile yapılan know-how anlaşması, 1993 yılında Ceac firması ile yapılan ortaklık ve daha sonra bu ortaklığın Exide firması ile devam ettirilmesi İnci Akü'nün küresel vizyonunu ortaya koymuştur. Starter ve endüstriyel olarak kategorize ettiği ürünlerini ihraç ettiği ülke sayısı 2014 yılında 84'e yükselmiştir. Bu ürünlerin yurtdışı satışları, yurt içi satışlarını geçerek toplam satıştaki payı yüzde 60'a ulaşmıştır.

\subsection{GS Yuasa}

Bir Japon firması olan GS Yuasa International Limited, 10 milyar yen sermaye ile 2004 yılında kurulmuştur. Yaklaşık 13609 çalışanı bünyesinde bulunduran dev şirket, yaklaşık 100 yıllık geçmişi olan GS Yuasa şirketler topluluğunun çatısı altındadır. GS Yuasa International, başlıca otomobil aküleri, endüstri aküleri, güç kaynağı sistemleri, salt tesisi, aydınlatma donanımı ve mor ötesi sistemleri üretmektedir. Hali hazırda Asya ve Afrika pazarlarında çok güçlü olan GS Yuasa, belirlemiş olduğu "inovasyon ve büyüme" vizyonu ile okyanus aşırı pazarlarda da etkin olmayı hedeflemektedir. Bu paralelde belirlemiş olduğu 5 adet stratejik hedeflerden bir tanesi Avrupa pazarında da büyüyerek küresel pozisyonunu güçlendirmektir.

\section{BULGULAR}

\subsection{Istaş ve Petrofer Ortak Girişimi ile Sonuçlanan Süreç}

70 milyonu aşan ve büyüyen bir pazar olmasının yanı sıra, coğrafi konumu nedeniyle Türkiye, çevresindeki ülkeler ile birlikte (Ortadoğu, Kuzey Afrika, Türki Cumhuriyetleri) Petrofer için ciddi bir potansiyeldi. Bu sebeple ortak olarak aradıkları işletmelerin yöneticilerinin de çevrelerini iyi tanımaları ve kolaylıkla ilişki kurabilme yeteneklerine sahip kişilerden olmalarına ihtiyaçları vardı. Istaş'ın Genel Müdürü olan Tamer Taşkın'ın o yıllardaki girişimci ve aktif kişiliği Petrofer'in aradığı uluslararası bir ortak için aradığı özellikler arasındaydı. Petrofer'e ilk kez temsilcilik almak için yanaştığı zaman Petrofer'in hali hazırdaki temsilcisinden 10 kat fazla satış yapacağının teminatını vermişti. Bu sözünü aynı yıl içerisinde gerçekleştiren Istaş, Petrofer'in temsilcilerinden en aktifi olarak kendini kanıtlamış oldu ve Petrofer'in hedeflediği Kuzey Afrika pazarına girmeyi başarmasına ciddi bir katkıda bulunmuştu.

Ünlü düşünür Frank Crane'in:" Akıllı bir kişi samimiyetin dünyadaki en etkili kuvvet olduğunu anlar ve onunla müttefik olur" sözleri bir Alman firmasının, dünya ortağı olarak seçeceği işletmede neleri önemsediğini kısaca ortaya koymaktadır. Petrofer'in aradığı ortaklıkta verilen sözlerin tutulması yani "karşılıklı güven" inşa edilmesi çok önemliydi. Karşıııkı ilişkilere büyük önem veren Tamer Taşkın, Petrofer'in temsilcisi olduğu yıllarda kendisini ziyarete gelen Alman firmalarının yöneticilerini aileleri ile birlikte yıllar boyunca evinde ağırlayarak içten bir bağ kurulmasına yardımcı olmuştu.

Petrofer, Alman mantığına hakim olan, dolayısıyla iş disiplinine sahip, etik değerleri olan ve iletişimi kuvvetli işletmelerle iş yapmayı tercih ediyordu. Ayrıca Petrofer'in rekabetçiliğini sürdürebilmesi için Ar-Ge faaliyetleri kritik bir öneme sahipti. Öncelikle, Tamer Bey'in üniversite yıllarında bir Alman firmasında yapmış olduğu staj, Alman kültürünü çok iyi tanımasını sağlamıştı. Dolayısıyla, Istaş'ın kurulduğu andan itibaren insan kaynakları politikası olarak işletmeye alınan çalışanların çok dil bilen, görev odaklı olan ve Ar-Ge faaliyetlerini güçlendiren mühendislerden seçilmesine dikkat edilmişti. Bu politika sadece işe alım süreciyle sınırlı kalmayıp; daha sonraki zamanlarda da çalışanlarının eğitimine önem verilerek devam etmişti. Örneğin, İzmir Atatürk Kültür Merkezi'ne Almanya'dan konuşmacılar getirtilerek Istaş çalışanlarına eğitimler verdirilmiş; bu da işletmenin, kendisini geliştirme konusunda ne kadar hassas olduğunu Petrofer'e göstermişti.

Yıllar içerisinde Istaş'ın izlediği tüm bu yollar, Petrofer'in Istaş ile (\%50-\%50 ) ortak girişimde bulunmasını sağlayacak kadar ilgisini çekmişti. Yapılan ortaklıkla kurulan şirket 1995 yılında "Petrofer Türkiye" ismini almıştır.

\section{2. İnci Akü - GS Yuasa Ortak Girişimi ile Sonuçlanan Süreç}

GS Yuasa, Afrika, ve Asya pazarlarında oldukça güçlü olmasına karşın "Avrupa ve Türk Cumhuriyetleri" pazarlarına girmekte zorlanıyordu. Bu nedenle bu coğrafyadaki pazarlara güçlü ve hızlı bir giriş yapabilmek için uygun bir ortak arıyordu. Inci Akü'nün üretim merkezinin Manisa gibi tüm hedeflenen pazarlara deniz yoluyla ulaşabileceği İzmir limanına yakın olması önemli bir artıydı. Ayrıca İnci Akü izlemiş 
olduğu ihracat stratejisi ile müşteri portföyünü coğrafi bakımdan oldukça farklılaştırmıştı. İnci Akü'nün sahip olduğu bu iki özellik (lokasyon ve müşteri portföyü), GS Yuasa'nın hedeflediği pazarlara hızlı ve güçlü bir şekilde girmesini sağlayabileceğinden İnci Akü'yü ideal bir ortak adayı yapmıştı.

GS Yuasa, ürün geliştirme konusunda oldukça yüksek yetilere sahip mühendisleri çatısı altında bulundurmasına rağmen Japon mühendislerinin Avrupa'ya getirilmesi oldukça maliyetli olacaktı. $\mathrm{Bu}$ açıdan ortaklık kurulan firmanın da araştırma faaliyetlerine önem vermesi ve mühendislik konusunda ileri düzeyde olması Japon firması için oldukça önemliydi. İnci Akü ise ülke içinde ve dışında "inovasyona ve girişimciliğe" yıllar boyunca yatırım yapmış bir firmaydı. Örneğin, İnci Akü'nün çeşitli bakanlıklardan aldığı ürün geliştirme ve inovasyon konulu ödüller İnci Akü'nün teknik konularda da oldukça ehil olduğunu ispatlıyordu. Buna ek olarak ortaklık görüşmeleri sırasında da İnci Akü'nün yetenekli Türk mühendisleri, Japon mühendislerinin dikkatini çekmiş ve İnci Akü ile kurulacak bir ortaklıkta Japon mühendislerin ülkelerinden bu coğrafyaya getirilmesine gerek kalmamıştı.

GS Yuasa, ortak girişimin geri dönülmesi maliyetli bir stratejik karar olduğunu göz önünde bulundurarak ortaklık yapacağı firmanın daha önce ortaklık deneyiminin olmasını arzu ediyordu. Buna uygun olarak İnci Akü, kurucusu Cevdet İnci'nin felsefesi doğrultusunda hep yabancı firmalarla iş birliği yaparak büyüme modeline gitmişti. 1985'de İnci Akü, Avusturyalı Dr. Jungfer Baren 8 yıl süren bir knowhow anlaşması yapmıştı. 1993 yılında ise Fransız CEAC firması ile ortak girişimde bulunmuştu. Daha sonra akü sektöründe diğer bir dev olan Amerikan firması Exide'ın CEAC'ı alması sonucu ortaklığa bu firma ile devam etmişti. Bu ortaklık 2003 yılında, iki ortak arasındaki yaşanan anlaşmazlıklar yüzünden değil; Exide'ın yaşadığı finansal kriz nedeniyle bitirilmişti. İnci Akü'nün tüm bu yabancı firmalar ile iş birliği tecrübesi, GS Yuasa ile de uyumlu bir ortaklık yapabileceğine dair Japon firmasına bir teminat oluşturmuştu.

Yıllar içerisinde İnci Akü'nün izlediği tüm bu yollar, GS Yuasa'nın İnci Akü ile (\%50-\%50) ortak girişimde bulunmasını sağlayacak kadar ilgisini çekmişti. Yapılan ortaklıkla kurulan şirket 2015 yılında "Inci GS Yuasa Akü" ismini almıştır.

\section{BULGULARIN TARTIŞILMASI, GELECEĞE PROJEKSIYON VE SONUÇ}

Araştırılan iki Türk firmasının da sosyal sermayesini zaman içinde bulundukları aktivitelerle kuvvetlendirdikleri görülmüştür. Hem Istaş hem de İnci Akü bulundukları endüstrilerde lider olan küresel dev firmaların (Petrofer ve GS Yuasa'nın) dikkatlerini çekmiş ve böylece bu devlerin büyük potansiyellerinden ortaklık kurarak yararlanmışlardır. "Bu başarılı neticede Türkiye'nin jeopolitik pozisyonunun ve büyüyen dinamik bir pazar olmasının katkısı olsa da asıl kilit nokta vaka çalışmalarında incelediğimiz Türk firmalarının yıllar boyunca yaptığı faaliyetlerle sosyal sermayelerini güçlendirmiş olmalarıdır."

Araştırma çerçevesinde incelenen ortak girişimlerin kuruluş tarihleri arasında yaklaşık 20 yıl fark vardır. Her bir ortaklığın kendi zaman dilimi dikkate alındığında, aslında Istaş ve İnci Akü'nün sosyal sermayelerini büyütürken bulunduğu faaliyetlerde ve oluşturduğu organizasyon kültürlerinde benzerlikler olduğu göze çarpmaktadır. Dolayısıyla, sosyal sermaye teorisinin bileşenlerinin kullanılarak firmaların ortaklık kurma süreçlerinin bağdaştıııması bu araştırmanın başlıca teorik katkısını oluşturmaktadır.

Sosyal sermayenin üç boyutundan biri olan yapısal boyut, hem Istaş'ın hem de İnci Akü'nün yabancı dev ortaklarının açılmak istedikleri pazarlar için bulundukları network ağında önemli bir pozisyona sahip olduklarını göstermektedir. Bir diğer deyişle bu Türk firmalarının dev firmaların açılmayı planladıkları coğrafyalarda bağlarının güçlü ve çeşitli olması onları ortaklık için çekici hale getirmiştir. Fakat bu iki Türk firmasının network ağ yapıları karşılaştırıldığında geçen 20 yılın da etkisiyle network ağını oluşturan aktörlerin ve bu aktörleri birbirine bağlayan bağların farklılık gösterdiği gözükmektedir. Istaş'ın bulunduğu network ağında aktörler firmaların sahibi olan özel kişiler iken, bu aktörler arası kurulan bağlar da daha çok kişisel ilişkilerdir. İnci Akü'nün örneğinde ise kurumsallaşan iş yaşamının da etkisiyle network ağının aktörlerinin firmaların tüzel kişilikleri olduğu gözükmektedir. Bu aktörler arasında kurulan bağ ise kişisel ilişkilerden çok ticari ilişkilerdir.

Türkiye'nin Petrofer için hedef pazarlardan biri olması itibariyle ortaklık yapılacak firmanın Petrofer'e Türkiye'de hızlı bir yayılım sağlaması önemliydi. Istaş'ın kurucusu olan Tamer Taşkın'ın aynı zamanda 
EBSO Ege Bölgesi Sanayi Odası Meclisi'nde iki kez yönetim kurullarında görev alması; ve daha sonraki yıllarda ise başkanlık yapması Petrofer'e önemli bir veri olmuştu. Bu görevlerde bulunan bir kişinin firması ile ortaklık yapmak Türkiye network ağındaki tüm firmalara erişimin kolaylaşacağı anlamına geliyordu. Sonuç olarak da Petrofer için Istaş ile ortaklık seçimin ne kadar isabetli olduğu, "Petrofer Türkiye" ortak girişiminin 20 yıldan fazla bir süredir devam etmesi, birçok ülkeye ihracat yaparak büyümesi ve Türkiye'de sektöründe lider olması ile doğrulanmış oldu.

Asya pazarında oldukça güçlü olan GS Yuasa ise yapacağı ortaklık ile Avrupa ve Kafkasya gibi büyük coğrafi pazarlara başarılı bir giriş yapmayı hedefliyordu. Bu hedefe paralel olarak ortaklık kurmak istedikleri firmanın sadece müşteri portföyünün sayıca çok olması değil aynı zamanda coğrafi olarak da çeşitlenmiş olması gerekiyordu. Bu noktada İnci Akü'nün coğrafi olarak Avrupa ve Kafkas pazarlarına yakın olması ve daha önemlisi bu bölgelere yayılmış müşteri portföyü (84 ülke) GS Yuasa'nın ilgisini çekmiş ve böylece "İnci Akü GS Yuasa” ortaklığı kurulmuştur. "İnci GS Yuasa Akü" ortaklığı henüz çok yeni olduğundan başarısı hakkında konuşmak zor olsa da firma yetkililerinden alınan ilk bilgilerin oldukça olumlu olduğu dikkati çekmektedir.
Sosyal sermayenin ilişkisel boyuta bakıldığında ise Istaş'ın, ortaklıktan önce Petrofer firmasının Türkiye temsilcisi olması; İnci Akü'nün de Fransız ve Amerikan firmaları ile uzun süreli ortaklıklar kurmuş olması her iki Türk firmasının da iş birliği yapabilen ve bu iş birliklerini sürdürebilen firmalar olduğunu göstermektedir. Öğrenen örgüt olma ile ilgili olan bilişsel boyut dikkate alındığında ise, her iki Türk firmasının da ortaklık kurdukları firmaların örgüt kültürlerine öğrenen organizasyon olmaları dolayısıyla uyum gösterebilmişlerdir. Istaş, Petrofer'in henüz temsilcisi iken organizasyon kültürünü Petrofer ile uyumlaştırmıştır. Inci Akü ise kurucusunun belirlediği vizyon ile sürekli uluslararası iş birliklerinde bulunmuş ve böylece GS Yuasa'nın örgüt kültürüne kolaylıkla uyum sağlayabileceğini göstermiştir.

Yapılan araştırma göstermiştir ki; incelenen iki Türk firması da başarılarını hiç rastlantısal bir şekilde gerçekleştirmemiştir. Bu araştırmanın sonuçları gelecekte sosyal sermayesini kuvvetlendirerek küresel değer zincirine entegre olmayı arzulayan diğer Türk firmalarının yöneticilerine de birçok çıkarımlar içermektedir. Bu doğrultuda Türk firmalarının gelecekte dev firmaların dikkatini çekebilmeleri için aşağıda güçlü ve zayıf yönleri belirtilmiş; ayrıca sahip oldukları fırsatlar ile maruz oldukları tehditler de değerlendirilmiştir (Şekil 2).

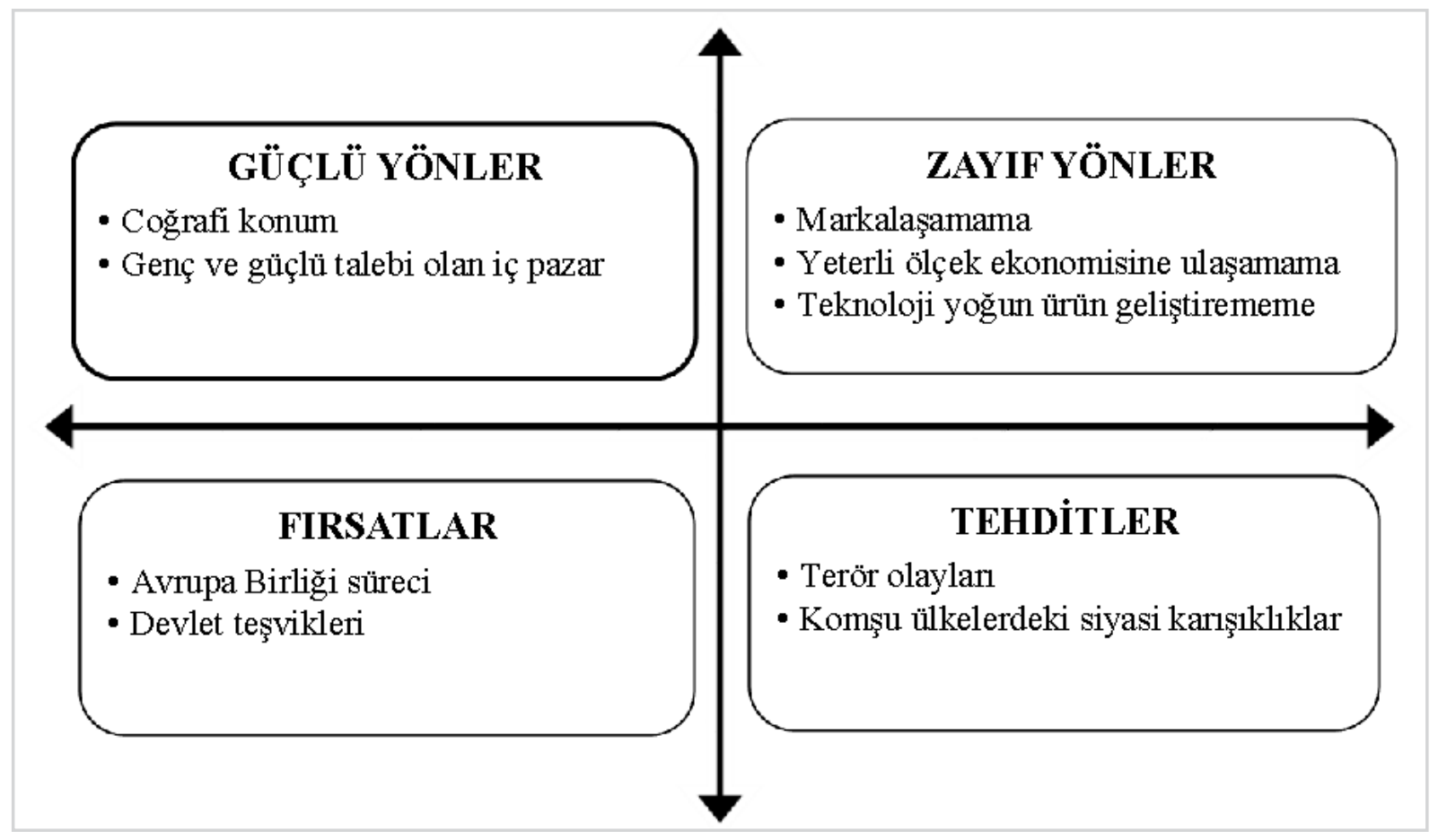

Şekil 2: Dev Firmalar ile Ortak Girişim Kurmak İsteyen Türk Firmaları için SWOT Analizi 
Günümüzde bir Türk firmasının, dev firmaların ortaklık için ilgisini çekmesini sağlayan en önemli faktör bulunduğu "coğrafi" konum olarak gözükmektedir. Türkiye, doğu ve batı pazarları arasında ciddi bir köprü görevi görmektedir. Dolayısıyla, Avrupa pazarlarına açılmak isteyen büyük Asya ve Afrika firmaları için Türk firmaları ile ortaklık, bu firmaların hedeflerine ulaşabilmeleri için önemli bir araç olabilecektir. Ayrıca Türk firmaları ile yapılacak olan bir ortaklık, genç ve talebin fazla olduğu Türkiye pazarında da etkin olunmasını sağlayacaktır.

Türk firmalarının sahip olduğu coğrafi avantaja karşın bazı zayıf yanları da dikkat çekmektedir. Özellikle Türk işletmelerinin "markalaşmamış" olmaları söz konusu dev firmalara ortaklık için yeterince "güven duygusu" vermemektedir. Ayrıca ülkemizdeki firma sahiplerinin "küçük olsun ama benim olsun" felsefesi önce küçük aile firmalarının ortaklık kurarak dev firmaların ilgisini çekecek yeterli ölçek ekonomisine sahip olmasına engel olmaktadır. Son olarak Türk firmaları daha çok "emek yoğun" ürün üretmektedirler. Oysa dev firmalar genellikle ortaklık kurmak istedikleri bölgesel firmaların Ar-Ge kaynaklı teknoloji yoğun ürün geliştirebilme becerisine sahip olmalarını arzu etmektedirler.

Türkiye'nin özellikle Avrupa Birliği'ne giriş aşamasında bulunması dev firmaların ilgisini çekmesinde önemli bir "fırsat" yaratmaktadır. Ayrıca ülkenin Doğu Bölgeleri'ne yapılacak yatırımlarda devlet teşviki alınabilmesi bu dev firmalar için de ortaklık için ciddi bir istek uyandırabilecek finansal destek sağlayacaktır. Buna rağmen bu bölgede terör olaylarının devam etmesi ve ülkemizin komşu ülkelerinde yaşanan siyasi karışıklıklar dev firmaların Türk firmaları ile ortaklık yapma girişimlerine "tehdit" oluşturmaktadır.

Özetle dev firmaların ilgisini çekmek isteyen söz konusu Türk firmaları, ortaklık kurmayı planladığı dev firmaların hangi pazarlara açılma eğiliminde olduklarını tespit ederek veya ürünlerini hangi teknoloji üzerine inşa edeceklerini araştırarak bu dev firmaların yetilerini tamamlayabilecek özellikleri edinmelidir. Bu özellikler, diğer bölgesel firmaların kolaylıkla edinemeyeceği özellikler olmalıdır ki Türk firmaları diğer bölgesel firmalardan kendilerini farklılaştırma imkânı bulabilsinler. Bu aşamadan sonra Türk firmalarına stratejik olarak şu tavsiyelerde bulunulabilir:

Ortak girişimde bulunulması hedeflenen dev firmaların network ağları tespit edilerek doğrudan onların temasta bulundukları iş ortakları ile bağlantı kurulmalıdır. Bu bağlantılar sonucunda oluşturulan iş aktiviteleri sayesinde hedeflenen dev firmaların örgüt kültürlerinin yapıları ve dinamikleri öğrenilebilmeli ve kendi işletme kültürleriyle uyumlaştırılmalıdır. Bu uyumun karşılıklı güveni inşa etmesi fonksiyonu sayesinde de ortaklık için "tercih edilen bir firma" olma imkânı sağlanmış olacaktır.

\section{KAYNAKLAR}

Adler, P. S. ve Kwon, S. W. (2002) "Social capital: prospects for a new concept"'. Academy of Management Review, 27: 17-40.

Barabel, M., Meier, O., ve Soparnot, R. (2015). "Asymmetric alliances between SMEs and large firms in the area of innovation: strategic determinants and cultural effects". Gestion 2000, 31(6): 87-106.

Borys, B. ve Jemison, D. B. (1989). "Hybrid arrangements as strategic alliances: Theoretical issues in organizational combinations". Academy of management review, 14(2): 234-249.

Bourdieu, P. (1980) “Le capital social: notes provisoires". Actes de le recherche scientifique et sociale, 30: 3-6.

Carnovale, S., ve Yeniyurt, S. (2014) "The role of ego networks in manufacturing joint venture formations". Journal of Supply Chain Management, 50(2): 1-17.
Chen, H., ve Chen, T. J. (2002) "Asymmetric strategic alliances: A network view". Journal of Business Research, 55(12): 1007-1013.

Choi, T., ve Kim, Y. (2008) "Structural embeddedness and supplier management: A network perspective". Journal of Supply Chain Management, 44 (4): 5-13.

Dacin, M. T., Hitt, M. A., ve Levitas, E. (1997). “Selecting partners for successful international alliances: Examination of US and Korean firms". Journal of world business, 32(1): 3-16.

Delios, A., ve Henisz, W. I. (2000) "Japanese firms' investment strategies in emerging economies". Academy of Management journal, 43(3): 305-323.

Eisenhardt, K. M. (1989) "Building theories from case study research". Academy of management review, 14(4): 532-550. 
Garvin, D. A. (2003) "Learning in action: A guide to putting the learning organization to work". Harvard Business Review Press.

Geringer, J. M. (1991) "Strategic determinants of partner selection criteria in international joint ventures". Journal of international business studies: 4162.

Giuliani, E., Pietrobelli, C., ve Rabellotti, R. (2005). "Upgrading in global value chains: lessons from Latin American clusters". World development, 33(4): 549573.

Glaister, K. W., ve Buckley, P. J. (1996) "Strategic Motives For International Alliance Formation". Journal of Management studies, 33(3): 301-332.

GS Yuasa (2015), http://www.gs-yuasa.com/en/ company/, (20.12.2015).

Gulati, R. (1998) "Alliances and networks". Strategic Management Journal, 19: 293-317.

Hamel, G. (1991) "Competition for competence and interpartner learning within international strategic alliances". Strategic management journal, 12(S1): 83103.

Hitt, M. A., Dacin, M. T., Levitas, E., Arregle, J. L., ve Borza, A. (2000). "Partner selection in emerging and developed market contexts: Resource-based and organizational learning perspectives". Academy of Management journal, 43(3): 449-467.

İnci Akü (2015), http://www.inciaku.com/tr/tarihce, (17.11.2015).

Inkpen, A. C., ve Beamish, P. W. (1997) "Knowledge, bargaining power, and the instability of international joint ventures". Academy of management review, 22(1): 177-202.

Inkpen, A. C., ve Currall, S. C. (1998). "The nature, antecedents, and consequences of joint venture trust". Journal of International Management, 4(1): 1-20.

Kangal, N. (2013) "Sosyal sermaye teorileri ve sosyal sermaye kalkınma ilişkisi: Türkiye örneği" Yayınlanmış doktora tezi, Selçuk Üniversitesi Sosyal Bilimler Enstitüsü.
Kogut, B. (1988). "Joint ventures: Theoretical and empirical perspectives". Strategic management journal, 9(4): 319-332.

Li, C. Y. (2012) "Knowledge stickiness in the buyer-supplier knowledge transfer process: The moderating effects of learning capability and social embeddedness". Expert Systems with Applications, 39(5): 5396-5408.

Marquardt, M. J. (1996) "Building the learning organization". New York, NY: McGraw-Hill Companies.

Nahapiet, J. ve Ghoshal, S. (1998) "Social capital, intellectual capital, and the organizational advantage" Academy of Management Review, 23(2): 242-266.

Nijmeijer, K. J., Fabbricotti, I. N., ve Huijsman, R. (2014) "Making franchising work: a framework based on a systematic review". International Journal of Management Reviews, 16(1): 62-83.

Otte, E., ve Rousseau, R. (2002) "Social network analysis: a powerful strategy, also for the information sciences". Journal of information Science, 28(6): 441453.

Park, G., Kim, M. J., ve Kang, J. (2015) “Competitive embeddedness: The impact of competitive relations among a firm's current alliance partners on its new alliance formations". International Business Review, 24(2): 196-208.

Petrofer (2015), http://www.petrofer.com/en/ company/petrofer-worldwide.html, (12.12.2015).

Prashantham, S., ve Birkinshaw, J. (2008). "Dancing with gorillas: How small companies can partner effectively with MNCs". California management review, 51(1): 6-23.

Tatoglu, E. (2000) "Western joint ventures in Turkey: strategic motives and partner selection criteria". European Business Review, 12(3): 137-147.

Todeva, E., ve Knoke, D. (2005) "Strategic alliances and models of collaboration". Management Decision, 43(1): 123-148.

Yin, R. K. (2013) "Case study research: Design and methods" Sage publications. 